\title{
IS AN ATHEIST UNJUST? THEISM VS. ATHEISM DEBATE IN THE LIGHT OF MORAL AND EPISTEMIC IMPERATIVES
}

\author{
JACEK WOJTYSIAK \\ John Paul II Catholic University of Lublin
}

\begin{abstract}
In the article I reconstruct Karol Wojtyła's argument against atheism. According to Wojtyła, an atheist is unjust because of not rendering absolute honour to God. In my opinion the argument is sound if one applies it to theists or negative atheists (but not to positive atheists) and if one presupposes that there are moral obligations to only supposed persons. The argument meets some objections (amongst others, the problems of multiplying obligations and the inability of an atheist giving honour to God). A discussion of them leads me to an interpretation of the theism-atheism controversy as being the conflict of two imperatives: the imperative of justice and the imperative of evidence.
\end{abstract}

\section{INTRODUCTORY REMARKS ${ }^{1}$}

Theism and atheism are not only philosophical doctrines, but also opposing ways of life and of knowing the world. ${ }^{2}$ Despite significant discrepancies, they probably share some common moral and epistemic

${ }^{1}$ This paper was presented at the conference 'Epistemology of Atheism' (Lorraine, June 2013). I thank all the participants of this conference - especially Paul Clavier, John Greco, Piotr Gutowski, Dariusz Łukasiewicz, Cyrille Michon, Roger Pouivet, Sebastien Rehault, and John Schellenberg - for their interesting critical remarks that helped me to improve (at least partly) my text.

${ }^{2}$ Theism as a philosophical doctrine claims that there is exactly one (metaphysically) ultimate, transcendent, personal and (morally) good being called God. The content of this doctrine can be extended or reduced. Therefore atheism can be understood strictly as a negation of this doctrine as a whole or as a negation of any its variety or part. The above distinction is significant for understanding practical theism and atheism, which are the ways of life with or without the relationship to God. My article deals with theism 
principles (imperatives). In cases where those principles conflict, theists and atheists differ in preferences as to the priority of one of the principles over the others. In this text, I will show this difference in preferences taking as an example the principle of justice, or the moral imperative of justice (MIJ), and the principle of evidence, or the epistemic imperative of justification (EIJ). I will attempt to show how the understanding and the position of those imperatives affect one of the aspects in the debate between theism and atheism.

The starting point of my considerations will be an intriguing essay by a Polish philosopher, Karol Wojtyła (1983/1958), later known as Pope John Paul II. ${ }^{3}$ In this article, he defends the claim that an atheist violates the (classically understood) principle of justice. After presenting Wojtyła's argument and rendering it more precise (sections II, III), I will show its premises related to the Thomistic concept of justice and religion (section IV). Next, I will consider an objection that may be raised against Wojtyła's argument (section V). This discussion will lead me to the interpretation of the theism vs. atheism controversy as the conflict between MIJ and EIJ (section VI). The analyses - which I will perform in sections VII-IX - of those imperatives (and their presuppositions) and of different varieties of atheism (and theism) will prove useful in the clarification of the controversy and in the assessment of Wojtyła's claim. Finally, I accept it with a modification, overcoming further objections against it and indicating cultural consequences of the decline in the attitude of religious reverence (section $\mathrm{X}$ and conclusion).

\section{THE ORIGINAL VERSION OF WOJTYŁA'S ARGUMENT}

Below I present the original version of Wojtyła's argument, making a list of quotations from his article (1983/1958). I put them in the order that represents the course of argument that may be attributed to Wojtyła.

(W1) 'To be just means to render what is due to a person [...]. Showing respect to the rights of persons who do not clearly and tangibly strive for it is a particular manifestation of justice.' (p. 109)

and atheism in the strict sense, however, after introducing the necessary changes, my argument can be applied to their reduced versions.

${ }_{3}$ Wojtyła's article cited here was written in 1957-1958. At the time, Wojtyła was a lecturer in ethics at the Catholic University of Lublin. All quotations from Wojtyła's text are in my translation from the original Polish. 
(W2) 'Reason alone leads man to the conclusion of the existence of the First Cause, which is the first being, i.e. God.' (p.107)

(W3) 'If God is the First Cause to which everything, and thus also man, owes its existence, therefore it is man, as a creature capable of knowing this truth, that should bring it to expression in his life [...].' (p. 107)

(W4) 'Doing this, he fulfils the elementary duty of justice.' (p. 107)

(W5) 'If he does not do it, he offends justice.' (p. 107)

(W6 - conclusion) '[An atheistic attitude] is ex definitione devoid of an [essential] manifestation of justice.' (p. 107)

(W1) is a quasi definition of justice. (W2) is an epistemologicalontological claim concerning the existence of God and the attainability of the rational knowledge of it. (W3) is a deontic consequence of the application of the quasi-definition (W1) to God whose existence is stated in claim (W2). From this consequence Wojtyła derives the evaluative statements: (W4) and (W5). The latter leads him to the conclusion (W6) on the injustice of an atheist's attitude. ${ }^{4}$

\section{A RECONSTRUCTION OF WOJTYŁA'S ARGUMENT}

Wojtyła's presentation of the argument is clear but informal and inexact. It is possible to give it a more precise form. Here is a proposal of how to do this. ${ }^{5}$

Let the variable $x$ represent an element in the set of people. Let us assume the following definition (equivalence).

\footnotetext{
${ }^{4}$ Wojtyła's article (and the above reasoning) does not directly concern the attitude of atheism, but the independent ethics proposed by an eminent Polish philosopheratheist Tadeusz Kotarbiński; he believed that moral norms should be derived from sources independent of religion (and worldview). According to Wojtyła, Kotarbiński's independent ethics is 'natural ethics', or even 'Christian ethics', 'minus all that refers to God in it' (1983/1958: 106). Thus it is no wonder that such ethics does not include norms regulating the relationships between man and God, which makes it poorer 'by one justice' (Wojtyła 1983/1968: 110). A person acting upon such ethics would in practice assume an atheistic attitude, which to Wojtyła is unjust by nature.

${ }^{5}$ Assigning symbols to the steps of the original reasoning of Wojtyła, I used the letter 'W' (from the first letters of his name). Now I am using letters 'WW' (from the first letter of Wojtyła's name and the first letter of my name). The argument could obviously be formulated even more precisely, but I would not like to let my care for its correctness blur its clarity and simplicity. I also do not address the question of the relationship between indicative and normative statements.
} 
(WW1) $x$ is just iff $x$ renders each person what is due to him or her. Note that a person's due mentioned in the definition refers also to God (if this person exists):

(WW2) Absolute honour is due to God as the Creator of the world and the highest and the best person.

So we can accept the following implication:

(WW3) If $x$ is just, then $x$ renders (also) absolute honour to God.

Performing a transposition, we obtain:

(WW4) If $x$ does not render (also) absolute honour to God, then $x$ is not just.

Because atheism consists, in practice, in not rendering honour to God, a person of whom the antecedent of this implication holds true may be called an atheist. ${ }^{6}$ Thus we are entitled to say that

(WW5) An atheist does not render absolute honour to God.

From (WW4) and (WW5) we infer, according to modus ponendo ponens, the conclusion:

(WW6) An atheist is not (in full) just.

The above argument presupposes the thesis of the existence of (a personal and good) God. If we accept this thesis, the argument can help us to understand the practical consequences of theoretical theism (see footnote 6). What if we do not accept this thesis? In this case we can state an objection that the argument can be sound only for theists (who have justified their theism). This problem will be developed in section V.

\section{THE PRESUPPOSITIONS OF THE ARGUMENT AGAINST THE BACKGROUND OF ST. THOMAS AQUINAS' CONCEPTION}

Wojtyła's argument rests on two presuppositions: (WW1) - the definition of justice, and (WW2) - the thesis about honour being due to God. I will

${ }^{6}$ A theoretical theist may also be a practical atheist, as it is possible to accept the thesis of the existence of God without rendering Him honour. Such an attitude, however, is inconsistent. Similarly, combining theoretical atheism with practical theism does not seem consistent (contrary to some philosophers of religion). We will return to this issue in further considerations, introducing additional distinctions. 
attempt to elucidate them in the context of St. Thomas Aquinas' views to which Wojtyła seems to refer.

Aquinas defines justice as follows (ST: 2a2ae, Q58, a1):

[...] justitia est habitus secundum quem aliquis constanti et perpetua voluntate jus suum unicuique tribuit ('justice is the habit whereby a person with a lasting and constant will renders to each his due').

This definition of justice - referring, among others, to Aristotle - presents it as a virtue that consists in maintaining appropriate proportions in relationships with other persons. The basis for those relationships may be, among others, a position those persons hold in relation to us in a hierarchy. The principle of rendering each his due is quite well rooted in our moral intuitions, although it may be interpreted and applied in various ways.

Aquinas applies this principle, among others, to the 'man - God' relationship. He is entitled to do this, because he holds a conviction (in his own opinion, legitimate and true!) that there exists the personal God. A variety of justice that refers to God he calls religion. Religion consists in rendering due honour to God ('paying [reddere honorem debitum] the debt of honour to God' (ST: 2a2ae, Q81, a2) or 'giving due honour to God' (ST: 2a2ae, Q81, a4)).

The ground for the binding force of the virtue (obligation) of religion is, according to St. Thomas, the highest position of God in the hierarchy of beings. Thus, if the criterion of whether honour is due to someone is this person's 'superiority' (excellentia - excellence) in relation to the one who gives honour (e.g. a father in relation to his son or a king to his subject), then special - highest - honour is due to God, because

'God infinitely surpasses and completely transcends all other things, his excellence is unparalleled.' (ST: 2a2ae, Q81, a4)

It is worth noting that St. Thomas infers the obligation of rendering (absolute) honour to God from His highest (absolute) ontic position, while Wojtyła (see above II W3) stresses the moment of gratitude to God for giving man the gift of existence. The two approaches can be reconciled and accepted under the following conditions:

(i) the absolute superiority of God over other beings is the consequence of (or is meaningfully related to) the fact that $\mathrm{He}$ is their creator;

(ii) creating something ex nihilo is the fundamental (primary, borderline) good or the paradigmatic form of goodness - without it nothing (except God) could achieve any good; 
(iii) it is admissible (by analogy or metaphor) to regard the fact of having received existence from God as a gift or a present, although (as a contemporary brilliant critic of theism has put it) if $\mathrm{A}$ is to make a gift to $\mathrm{B}$, then $\mathrm{A}$ and $\mathrm{B}$ must both already exist (Everitt 2004: 130). ${ }^{7}$

As we can see, both (WW1) and (WW2) can be clarified and defended in the context of the classic, and rather trustworthy, philosophical conceptions. Despite this, an atheist can easily raise a very serious objection against the discussed reasoning.

\section{AN ATHEIST'S OBJECTION AND WOJTYŁA'S RESPONSE}

Wojtyła (1983/1958: 107-108) realized that such an objection can be made and reconstructed it (as it were, on behalf of an atheist) in the following way:

[...] I may be just or unjust only in relation to someone who really exists; because I am not convinced about the real existence of God, therefore it is out of the question for me to commit an injustice to Him. Only a person who has [...] the belief that God exists [...] may be guilty of such an injustice.

In other words: the obligation to render honour to God concerns only those who accept the thesis of His existence. Thus the above reasoning is conclusive, but refers only to people who have theistic beliefs but do not follow their practical consequences (determined in the context of quite universally accepted moral principles). The reasoning, however, does not concern people whose system of beliefs can be qualified as atheism.

Wojtyła answers (1983/1958: 108-109) by stating that for the cited objection to be valid, 'it should be first [...] irrefutably proved' that God does not exist (and that 'man is an independent being'). He also suggests that such a 'proof' has never been given, since 'so many people, both very simple and very educated' are convinced of the existence of God, while others 'cannot with complete certainty reject the existence of God, but to greater or lesser extent reckon with His possibility'. Because of these doubts, an atheist is morally obliged to ask the following question:

${ }^{7}$ Let us observe that in many cultures of the world there is a deeply rooted obligation of gratitude to parents for the gift of life, despite the above semantic difficulty (and despite the fact that the recipient of that 'gift' - sometimes a difficult or painful one - has not asked for it). 
Yet, am I not unjust towards the Being of whose existence so many people are deeply convinced? Just like a person of a subtle, delicate conscience is anxious not to harm even his unknown fellow human beings, even unconsciously. (Wojtyła 1983/1958: 110)

As we can see, in his response Wojtyła attempts to limit the validity of the objection to a very narrow (in his opinion) group of atheists - those who, as a result of 'irrefutable proof', are certain that God does not exist. He also assumes that for the obligation of rendering honour (or more broadly: of being just) to be binding, the conviction of the very possibility of God's existence, and not of His actual existence, is sufficient. I will later try to make both suggestions more precise and to discuss them. Before I do this, however, I will reconstruct the essence of the 'theism vs. atheism' debate, as it appears in the light of the considerations I have presented so far.

\section{THE NATURE OF THE VITAL CONTROVERSY BETWEEN THEISM AND ATHEISM}

In our lives we are guided by various moral and epistemic imperatives. Two of them are particularly important to our issue. The first is the moral imperative (or principle) of justice (MIJ), which can be formulated as follows:

(MIJ) Render to each his due!

The second one is the epistemic imperative (or principle) of justification (EIJ). Let us express it by the words:

(EIJ) Accept only the beliefs for which you have sufficient justification! ${ }^{8}$

The moral imperative of honour (MIH) with which theists (religious people) express their obligation of justice towards God is a particular variation of MIJ. This variation says:

(MIH) Render absolute honour to God! ${ }^{9}$

${ }^{8}$ EIJ corresponds to the famous principle of evidentialism that William Clifford expressed in the following way: 'it is wrong always, everywhere, and for anyone to believe anything on insufficient evidence'. I do not enter here into a discussion about this principle's validity. See Alvin Plantinga (2000: 67-107, esp. p. 89).

${ }^{9}$ In order not to become entangled in cultural limitations, we can initially formulate $\mathrm{MIH}$ as follows: Render absolute honour to whoever is worthy of it! We simultaneously 
Usually MIJ and EIJ do not conflict. However, there may arise a conflict between EIJ and the mentioned MIJ variation, i.e. MIH. An atheist might still say:

(A) I cannot fulfil MIH (MIJ in reference to God) because, in order to do this, I would have to accept the existence of God; then, however, I would violate EIJ, which is a priority imperative to me.

To such a declaration, a theist might respond as follows:

(T) The exact fulfilment of EIJ in reference to the belief concerning the existence of God is impossible; if 'God infinitely surpasses and completely transcends all other things', His superiority is incomparable, no human being can have (in a natural way) such knowledge of Him as to acquire sufficient grounds to accept a belief in His existence; ${ }^{10}$ however, rigorous respect for EIJ in reference to God leads to the violation of MIH, which I consider as the fundamental variation of $\mathrm{MIJ}$ - the imperative that has priority in my life.

As we can see, in practice the 'theism vs. atheism' controversy is (or sometimes happens to be) a controversy based on a conflict between two imperatives: MIJ (MIH) and EIJ. It is no wonder that sometimes the attitude of atheism causes moral outrage among theists: after all, atheists seem to violate MIJ (MIH). On the other hand, the theistic (religious, cultic) attitude not infrequently makes atheists respond with what I would call epistemic scorn: How can one engage in any activity towards a person whose existence is disputed or doubtful? Such an attitude clearly seems to violate EIJ.

It follows from the above that the key to understanding this essential aspect of the 'theism vs. atheism' controversy is the question whether MIJ (MIH) and EIJ are binding. Below, I will draw attention to some problems related to those imperatives, which might help clarify, and perhaps solve or weaken the mentioned controversy (conflict). Discussing those

assume that only a perfect (also morally perfect) person and the one that is distinguished from us and from the world by absolute ontic pre-eminence is worthy of such honour. This person is commonly called God.

${ }^{10}$ See above section IV. We can know God only by effects of His activity, but if God infinitely surpasses His effects, natural knowledge about Him seems to be impossible. No human knowledge about God - knowledge based on the acquaintance of imperfect objects present in the world - can grasp Divine essence. What is more, each attempt at such knowledge - as an attempt at the 'objectification' of God - would violate God's majesty. 
problems I will use, among others, the above listed suggestions made by Wojtyła in his answer to an atheist's objection.

\section{EPISTEMIC IMPERATIVE OF JUSTIFICATION}

Those who accept the validity of EIJ must remember that its exact fulfilment encounters serious difficulties in practice. We do not have enough time and appropriate means to justify all our beliefs. A great part of our beliefs we hold without a sufficient justification, but it would be difficult to dispense with them in life. We also know that different standards of justification - from more rigorous to more liberal - are applicable to different types of beliefs, and philosophy is an area where it is difficult to find irrefutable justifications and decisive criteria to settle disputes between conflicting beliefs.

I believe that the application of EIJ to philosophical (and worldviewrelated) discussions should consist in rejecting completely unjustified beliefs and accepting the beliefs for which their proponents can find appropriate reasons. It is enough that those reasons are understandable and disputable to the opponent and that bringing them up for discussion may lead its participants to change their positions. If we accept the above criterion, we may find that at least some theists and some atheists respect EIJ with regard to the beliefs that identify them. From now, speaking of 'theism/atheism', I will refer to rational (justified in the above sense) theism/atheism.

\section{TWO TYPES OF ATHEISM}

In this context, it is worthwhile to cite the distinction between two types of atheism proposed by Michael Martin (2007: 1) in his introduction to The Cambridge Companion to Atheism. According to him:

- a negative atheist is 'someone without a belief in God; he or she need not be someone who believes that God does not exist';

- while a positive atheist is the 'one who believes that there is no God.'11

${ }^{11}$ My reasoning is limited here in the first place to the 'atheism in the narrow sense', which refers to the theistically understood God (and not to God, or god, understood in any way). However, as I previously remarked, after the necessary modifications, it can also be applied to atheism in the wider sense. 
Martin (2007: 2) adds that

For positive atheism [...] to be successfully defended, two tasks must be accomplished. First, the reasons for believing in a theistic God must be refuted; in other words, negative atheism [...] must be established. Second, reasons for disbelieving in the theistic God must be given.

Applying the above distinction to MIH question, it is easy to note that an atheist who accomplished the above two tasks - that is, whose views can be qualified as justified positive atheism - is not bound by MIH, because such an atheist is justified in believing that God does not exist. But what about a negative atheist - one that justified his rejecting the reasons for theistic belief (and thus justified 'the absence of belief in a personal theistic God'), but has no 'reasons for disbelieving in the theistic God' (and thus no reasons for believing that 'there is no God')?

\section{MORAL IMPERATIVE OF JUSTICE AND EXISTENTIAL BELIEFS}

In order to answer the question whether a negative atheist is bound by MIH, it is necessary to consider if there are situations where MIJ is binding despite the absence of belief in the existence of the person to whom we owe something. Since,

- if there are situations where someone should adhere to the principle of justice although he is not convinced that the person towards whom he is obliged to act justly exists, and at the same time has no justified belief that this person does not exist,

- it can be suspected that MIH is binding also for someone who is not convinced that God exists, although at the same time he has no justified belief that God does not exist.

Let us consider two situations.

(1) I am driving at night through a non-built-up area. I have no good reasons to assume that there is a pedestrian there at that hour. However, I have no sufficient reason to exclude such a possibility or to believe that there is (for certain) no pedestrian on the road. However, MIJ, or a similar moral principle (otherwise included in the traffic code), tells me to drive with caution: if it turned out that a pedestrian was walking along that road, I might harm him, and he has a right to inviolability.

(2) In my garden, where there are no apple-trees, I have found a large quantity of tasty apples. I have no sufficient reasons to believe that I was 
given them by my neighbour (who has an apple-tree): he does not like me and is mean. On the other hand, I have no grounds to believe that the apples are not a present from my neighbour: wind would not blow all those apples here, and other neighbours live too far. Worse still, I have neither the time nor the means to make a quick inquiry into the cause of the presence of the apples in my garden. I believe that in this situation I am - according to MIJ - obliged (at least conditionally) to thank my neighbour for delivering apples: thanks are always due to the donor.

I believe that it is possible to multiply examples of situations where as we are inclined to presume - someone has obligations, although he is not sufficiently convinced of the existence of the person to whom he is obliged. ${ }^{12}$ Both above examples, despite the difference between them, meet this condition. Obviously, the obligation in situation (1) is clearer - the danger of harming someone is the reason why not the belief in the existence (here and now) of a pedestrian, but the belief in the very possibility of his existence constitutes a sufficient ground for an obligation to certain behaviours. In the case of MIH, no one is harmed if this imperative is not fulfilled. There is, however, a danger of taking a wrong stance towards an alleged person who deserves gratitude or honour.

Case (2) quite closely resembles the position of a negative atheist towards God. The gardener would not harm the neighbour if he did not thank him. What is more, the gardener is not convinced that there is a donor of apples and that this donor (deserving thanks) is the same person as his closest neighbour. However, it seems that in view of the absence of sufficient reasons for the thesis that there is not a donor identical with the neighbour, the gardener has a duty to thank the neighbour (in some way). If he does not do it, his relationship to the neighbour will not be right.

Perhaps our situation in life is similar to that of the gardener. We live, but we cannot give the ultimate metaphysical explanation to our life. We

12 I do not insist that cases (1) and (2) are typical and incontrovertible examples of such situations. They are only meant to show that there are events in life that call for reflection regarding whether they possibly entail obligation towards persons of whose existence we are not sufficiently certain. To give another example: It is generally believed that one should not detonate a building if there may be people inside. The principle discussed here is also cited by anti-abortionists who claim that it is forbidden to destroy a human foetus even if we were unable to determine the precise moment when the life of the human person begins. 
have no proof demonstrating that our life is a gift from God. However, we have also no reasons to irrefutably exclude this possibility. ${ }^{13}$ If it turns out that this possibility obtains, and we have not rendered honour to God, it will also turn out that we have violated MIJ. Thus it seems that Wojtyła is right when he extends MIH application to people who do not believe in the existence of God, but (as I quoted above) 'reckon with His possibility'.

\section{OBJECTIONS AND ANSWERS}

The above analyses have led me to the thesis that MIH binds both theists and negative atheists, that is people who are not convinced of the existence of God but do not have sufficient reasons for their disbelieving in God. It is worthwhile to confront the claim I am defending with some possible objections and counterarguments.

(C1) Counterargument from multiplying obligations. If the very possibility of the existence of MIJ object binds us to apply the principle, we find ourselves in a situation of having a great number of obligations. This might paralyse our action: apart from being obliged to fulfil duties to real individuals that we know, we would be obliged to fulfil duties to individuals that are only supposed - including God. It is difficult to fulfil all those obligations efficiently.

Answer. Obviously, some limitations should be put on the validity of MIJ towards only supposed individuals. Perhaps such a limitation can follow from establishing the probability of the belief in the existence/ nonexistence of a given person (or the degree of probability we are inclined to attribute to the existence/nonexistence of a given person), above/below which MIJ would not be binding. However, it is difficult to develop such a theory of probability, as it would have to be different for different types of MIJ application.

I believe that here it is enough to refer to an intuitive sense of the importance of the matter: some obligations are so important that they are binding even in the case (like in situation (1) - see above: IX) where we admit only a possibility of the existence of their object; other obligations

13 This concerns especially the variety of negative atheism that follows from agnosticism: the 'position of neither believing nor disbelieving that God exists' (because of a lack of 'good reasons' for both attitudes - sceptical agnosticism; or because of 'equally good reasons' for both reasons - cancellation agnosticism) (Martin 2007: 2-3). 
are not so important - they are binding only when the existence of their object is obvious. In my opinion, the obligation contained in MIH belongs to the first category. The fact of our life is the fundamental metaphysical datum; if we admit the possibility that our life is a gift of God, or remains in an essential relationship to God, we owe Him gratitude or honour as an attitude that expresses this relationship.

(C2) Counterargument from the hiddenness of God. If there are no reasons sufficient to incline all rational subjects to belief in God's existence, then either God does not exist, or He deliberately hides his existence. The first case invalidates $\mathrm{MIH}$, because it is impossible to render honour to someone who does not exist. The second case invalidates $\mathrm{MIH}$, because the hiddenness of God indicates that He does not want to be known and rendered honour towards.

Answer. As to the first case. The thesis that God does not exist does not follow from the thesis that there are no proofs of the existence of God that convince everyone. Above, I attempted to show that only those who can demonstrate the truth of the first thesis are exempt from MIH.

As to the second case. We do not know motives for which God decided to remain hidden or not to reveal Himself clearly. Perhaps God wants to be known and honoured, but - as Wojtyła (1983/1958: 109) writes - 'does not impose Himself [or does not want to impose] on man with His rights'. Wojtyła mentions two supposed reasons of this 'non-imposing Himself': the unwillingness to violate human freedom (compare Swinburne 2004: 267-272) and the lack of consent to the violation of God's majesty (see above: VI. (T)).

In addition, let us observe that the fact that someone gives us a gift secretly or anonymously does not exempt us from the duty of gratitude. If we are unable to identify or find the giver, we are obliged at least to assume an intentional attitude of gratitude to him. This remains valid also for our supposed creator.

(C3) Counterargument from evil. A negative atheist is not obliged to respect $\mathrm{MIH}$, if he discovers in the world (or in his life) so great evil or such a kind of evil - created or allowed by God - that it cancels His deserving honour.

Answer. If the fact of evil in the world falsifies the thesis of the existence of a God that is good and deserves honour, then an atheist has sufficient reasons to be convinced that the theistic God does not exist. 
Then, however, he is not a negative atheist, but a positive one, so MIH does not bind him (as I indicated above).

(C4) Counterargument from inability. It is difficult to imagine how a negative atheist could follow $\mathrm{MIH}$ in practice. If he does not believe in God, he is unable to perform religious practices sincerely. He might imitate some external religious behaviours, but without an inner attitude that results from determinate theistic convictions.

Answer. The situation of a negative atheist who wants to follow MIH in practice is difficult, but not hopeless. I suppose that there are at least three possible ways to give honour to God without the belief that $\mathrm{He}$ exists: by a morally good life (i.e. a life that includes moral respect to all beings treated as if they were God's creatures or images); by refraining from the criticism of religious cult or opposition to it; by an intentional stance of conditional gratitude or conditional worship.

The last way could be expressed by the following prayer: 'If God exists, then I worship you God!'14 This prayer seems strange, but we can find the analogies in some human behaviours (e.g. when we knock on the door of a lonely house, saying if there is anyone in there, open!'). What is more, the fact that a negative atheist admits the truth of the antecedent of this implication, makes the implication valid for him.

The problem of the way of rendering honour does not concern only a negative atheist. As St. Thomas Aquinas writes (ST: 2a2ae, Q81, a2, ad3):

It belongs to the dictate of natural reason that man should do something through reverence for God. But that he should do this or that determinate thing does not belong to the dictate of natural reason, but is established by Divine or human law.

Thus it is clear that a lack of rational regulations concerning the way of rendering honour to God allows for a certain freedom in the choice of the way to fulfil MIH. This freedom may be limited by conscious (rationally motivated) and free membership of a determined religious or cultural community. A negative atheist has no moral obligation to participate in such a community. It seems, however, that - in the light of MIH - he has a moral obligation to refrain from the depreciation of a public religious cult, if this cult does not violate an important moral norm or lead to superstition. This condition, however, as Aquinas emphasizes (see ST: 2a2ae, Q81, a5, ad3; Q92-94, esp. Q92, a1), concerns theists also.

${ }^{14}$ N.B., I am afraid that today many nominal Christians pray in this way. 


\section{CONCLUSION}

In the present text I attempted - with the aid of philosophical arguments to defend the thesis that MIH binds not only theists but also negative atheists (but not positive atheists). Certainly, those arguments would not convince everybody to the thesis I defend. I hope, however, that they enabled at least some clarification of one of the important aspects of the debate (conflict) between theism and atheism.

Considering the practical dimension of the controversy, it is also worthwhile to ask about the cultural consequences of atheism disseminating. I believe the main consequence is - speaking in the language assumed above - the weakening or atrophy of the attitude of rendering absolute honour to God. But what happens if one does not render absolute honour to (supposed) God? I believe that there are two possibilities:

- rendering absolute honour to persons or things that do not deserve it (as in the totalitarian cult of power, and perhaps also in the consumers cult of material things or the cult of show-business stars in entertainment);

- the absence of absolute honour to anyone or anything.

The evil of the cultural consequence of the first possibility is today universally known. Yet the evaluation of the cultural consequences of the second possibility remains an open issue. I doubt, however, that it is possible to live without the attitude of absolute reverence, without simultaneously falling into nihilism or value relativism.

\section{BIBLIOGRAPHY}

Everitt, Nicholas. 2004. The Non-Existence of God (London - New York: Routledge)

Martin, Michael. 2007. The Cambridge Companion to Atheism (Cambridge: Cambridge University Press)

Plantinga, Alvin. 2000. Warranted Christian Belief (Oxford: Oxford University Press)

Swinburne, Richard. 2004. The Existence of God, (Oxford: Clarendon Press)

Wojtyła, Karol. 1983/1958. Etyka niezależna w świetle idei sprawiedliwości, in Elementarz etyczny (Lublin: TN KUL, 1983), pp. 103-110

St. Thomas Aquinas. [ST]. Summa Theologiae. Latin text and English translation, introductions, notes, appendices and glossaries by K. D. O’Rourke OP, vol. 39 (2a2ae. 80-91), reprinted in Religion and Worship (Cambridge: Cambridge University Press, 2006) 